\title{
A PATTERN OF FLAWS: FURTHER REFLECTIONS ON CAMBRIDGE UNIVERSITY PRESS'S EDITION OF THE LITERARY WORKS OF JOSEPH CONRAD
}

\author{
Cedric Watts \\ University of Sussex
}

Cambridge University Press's vast project to produce authoritative new editions of the literary works of Joseph Conrad is now well advanced; but the project is flawed. (I specify "the literary works" because I am not concerned with the admirable volumes of Conrad's letters.) With the exception of one volume, The Secret Agent, the immensely industrious and conscientious editors of the Cambridge series made a big mistake. They thought they knew better than Conrad.

The Cambridge editors show that Conrad usually accepted, by choice or acquiescence, the house styling and corrections that various publishers imposed on his work (sometimes he saw the changes at the proof stage, sometimes he did not); but these editors think that, on the whole, he should not have accepted the changes. They have therefore deleted much house styling and correction: "successive layers of non-authorial intervention affecting wording and 'accidentals' - punctuation, spelling and word-division". (I quote p. 307 of the Cambridge edition of Notes on Life and Letters, ed. J. H. Stape with the assistance of Andrew Busza, 2002.) The result of the Cambridge editorial procedures is a Conradian prose which is often impoverished and is sometimes even ungrammatical.

I am well aware that the Cambridge editors have done magnificent work in correcting long-established errors and in bringing to light Conradian words, phrases, sentences and even passages which otherwise would have been lost. Nevertheless, I deplore what, all too often, they have done to Conrad's style. My criteria are: logical clarity and rhetorical effectiveness.

It is obviously not my task, in this essay, to explore the great diversity of problems and principles involved in the production of the Cambridge edition. Such an exploration would be digressive, obscuring the issue. My task here is simply to demonstrate 
the presence of a pattern of flaws. If, after considering the evidence cited below, you agree that these flaws are present, I will have done my job.

2

My article entitled "The Stricken Series" is being published in Issue 10 of Conrad Studies: Journal of the Joseph Conrad Society of Japan (2019). In that article, I list flaws that I postulate in the following parts of the Cambridge University Press series of the literary works of Joseph Conrad: Almayer's Folly, A Personal Record (in particular "A Familiar Preface"), Heart of Darkness, and An Outcast of the Islands. My criticisms of the Cambridge Victory volume are being published in a forthcoming issue of Conradiana. In a further article, I consider some other volumes which have appeared in the Cambridge series: Notes on Life and Letters, 'Twixt Land and Sea I Tales, Last Essays, Lord Jim, and The Nigger of the "Narcissus". In the present article, I discuss the remaining volumes which (at the time of writing these words) have so far appeared: The Rover, edited by Alexandre Fachard and J. H. Stape (Cambridge: Cambridge University Press, 2018), and Suspense, edited by Gene M. Moore (Cambridge: Cambridge University Press, 2011).

First: The Rover. I invite the reader to consider the following two sequences and to decide which is better. For the sake of brevity, my examples are taken only from the first five chapters of the novel. Page-numbers are in brackets.

Here is Sequence A:

A1 (10) There the memories of his native country stopped, overlaid by other memories with a multitude of impressions of endless oceans, of the Mozambique Channel, of Arabs and negroes, of Madagascar, of the coast of India, of islands and channels and reefs, of fights at sea, rows on shore, desperate slaughter and desperate thirst, of all sorts of ships one after another, of merchant ships and frigates and privateers, of reckless men and enormous sprees.

A2 (13) It is n't a trifle.

A3 (13) two bags of mixed coins, gold mohurs, Dutch ducats, Spanish pieces, English guineas.

A4 (14): He found however that this secret garment which was worth precisely its weight in gold tried his endurance more than he had expected.

A5 (20-21) He was touched by a soft indefinite emotion and as her eyelids remained lowered till her black lashes seemed to lie like a shadow on her pale cheeks there was no need for him to force a smile.

A6 (23) It was too far - too big also, not distinct enough. 
A7 (27) He turned away from the window and found himself face-to-face with the sans-culotte who had apparently come up to him from behind [...].

A8 (33) After putting the razor away carefully Peyrol introduced his stockinged feet into a pair of sabots of the very best quality [...].

A9 (33): He crossed the kitchen into the salle which was cool [...].

A10 (34): the patriot dragged his dirty clogs low spiritedly in the fresh light of the young morning in a way no real worker on the land would ever do [...].

A11 (35): What do you expect.

A12 (38): He stood up and buckled the belt on while Peyrol rose more deliberately from the bench and said:

"She can't be where we saw her at anchor last night. [...]"

A13 (44): She never interfered with their private affairs and allowed the small coasting craft to go to and fro unmolested.

A14 (44): getting into motion in a very wide-awake manner he superintended himself the despatch of that boat [...].

A15 (44): the captain's own gig, a very fast pulling boat.

A16 (50): If she had not come out of a grave then she had jumped out of bed.

A17 (51): For it was unconceivable that he should have ventured inland and got captured there. It was equally inconceivable [...].

Sequence B:

B1 (8): There the memories of his native country stopped, overlaid by other memories, with a multitude of impressions of endless oceans, of the Mozambique Channel, of Arabs and negroes, of the coast of India, of islands and channels and reefs; of fights at sea, rows on shore, desperate slaughter and desperate thirst, of all sorts of ships one after another: merchant ships and frigates and privateers; of reckless men and enormous sprees.

B2 (12): It isn't a trifle.

B3 (12): two bags of mixed coins: gold mohurs, Dutch ducats, Spanish pieces, English guineas.

B4 (15): He found, however, that this secret garment, which was worth precisely its weight in gold, tried his endurance more than he had expected.

B5 (23): He was touched by a soft indefinite emotion, and as her eyelids remained lowered till her black lashes seemed to lie like a shadow on her pale cheek, there was no need for him to force a smile.

B6 (23): It was too far - too big — also not distinct enough.

B7 (31): He turned away from the window and found himself face-to-face with the sans-culotte, who had apparently come up to him from behind [...].

B8 (39): After putting his razor away carefully, Peyrol introduced his stockinged feet into a pair of sabots of the very best quality [...].

B9 (39): He crossed the kitchen into the salle, which was cool [...].

B10 (39): the patriot dragged his dirty clogs low-spiritedly in the fresh light of the young morning, in a way no real worker on the land would ever do [...].

B11 (40): What do you expect? 
B12 (45): He stood up and buckled the belt on, while Peyrol rose more deliberately from the bench, and said:

"She can't be where we saw her at anchor last night. [...]"

B13 (53): She never interfered with their private affairs, and allowed the small coasting craft to go to and fro unmolested.

B14 (53): getting into motion in a very wide-awake manner, he superintended himself the despatch of that boat [...].

B15 (53): the captain's own gig, a very fast-pulling boat.

B16 (62): If she had not come out of a grave, then she had jumped out of bed.

B17 (63): For it was inconceivable that he should have ventured inland and got captured there. It was equally inconceivable [...].

Sequence A helpfully italicises French words, but otherwise Sequence B is superior. Sequence A was taken from the Cambridge edition, 2018. Sequence B was taken from the "Collected Edition" of The Rover (London: J. M. Dent \& Sons, 1948).

A1 has a monotonously repetitive structure. B1 uses semi-colons and a colon to relieve and clarify the sequence. The first semi-colon separates locations from actions; the colon appropriately introduces a list of three kinds of vessel; and the second semi-colon separates the vessels from the actions of the men. The long sentence thus gains logical clarity and rhetorical effectiveness. In A2, the separation of " $n$ ' $t$ " from "is" looks odd, indeed archaic. B2 is correct. A3 permits the false reading that there were mixed coins in addition to the gold mohurs, etc. B3's colon offers the logical clarification: the mixed coins consisted of the gold mohurs, etc. A4, lacking commas, solicits a relatively rapid reading; B4 permits a clearer and more expressive reading. The commas of B5 clarify the structure of a sentence which, in the A5 version, is markedly under-punctuated. The second dash of B6 is, again, clarifying. Lacking the dash and having a redundant comma, A6 is unclear. B6 shows that being "not distinct enough" is the case both when it is too far and when it is too big, whereas A6 gives the wrong impression that it is only when it is too big that it is not distinct enough. A7 can be taken to mean that of two or more sans-culottes, one had apparently "come up to him from behind"; whereas the correct punctuation of B7 tells us that only one sans-culotte is present. A8, under-punctuated, is ambiguous: the adverb "carefully" could apply to the way in which Peyrol "introduced his stockinged feet". B8, correctly punctuated, shows that "carefully" applies only to the putting-away of the razor. A9, lacking a comma, could be taken to mean that of two or more salles, Peyrol chose the one which was cool. The comma of B9 tells us that there was one salle, and that it was cool. The "low-spiritedly" of B10 is more idiomatic and clearer than the "low spiritedly" of A10, and the comma of B10 helpfully separates the "in a way" from "the young morning".

The question at B11 correctly ends in a question-mark; the question at A11 fails to do so. A12, being under-punctuated, wrongly gives the impression that the speaker is Peyrol. The correct punctuation of B12 enables the reader to understand that the speaker is the young lieutenant and not Peyrol. A13, lacking a comma, wrongly lets the adverb "never" apply to "allowed" as well as "interfered"; the comma of B13 
shows that "never" applies only to "interfered". The comma of B14 clarifies the sense. A15 briefly permits the erroneous reading that this "pulling boat" is "fast"; the hyphen of B15 makes clear at once that the boat is "fast-pulling". A16 wrongly permits the "then" to govern the coming out of a grave; the comma of B16 correctly links the "then" to the jumping out of bed. In A17, "unconceivable" looks wrong (the Concise Oxford Dictionary lacks it), though it is a possible alternative spelling; but it is obviously inconsistent with the "inconceivable" in the following sentence. B17 consistently maintains "inconceivable".

4

Next, I consider the Cambridge text of Suspense, edited by Gene M. Moore (2011). Again, for the sake of brevity, my examples are taken only from the first five chapters of the novel.

Here is Sequence A:

A1 (4): Her tall spars overtopped the roofs of the houses and the English ensign at her flagstaff had been just hauled down and replaced by a lantern [...].

A2 (4): "[...] Why did you do that in the name of all the saints?"

A3 (6): "[...] Or is it only the darkness that makes her seem so."

A4 (6): "[...] Different men different wisdoms."

[...] "Different men, different wisdoms," he repeated, musingly.

A5 (9): For what can you possibly have to do here.

A6 (10): And now, will the Signore do what I ask him and return to his inn which is a much safer place than this platform?

A7 (11): The Englishman beheld with surprise his lately inimical companion squeeze himself between the massive tube of the piece of ordnance and the wall of stone and wriggle outwards into the depth of the thick embrasure till nothing of him remained visible but his black stockings and the soles of his heavy shoes.

A8 (11): Cosmo enlisted in these mysterious proceedings, the nature of which was becoming clear enough to him, obeyed at once [...].

A9 (12): For wouldn't a ghost be a thing of spirit, a man's soul itself made restless by grief, or love, remorse or anger.

A10 (15): his father, Sir Charles, and his sister Henrietta.

A11 (16-17): With habits of meticulous order and a marvellously commonplace mind she had a temperament which if she had not fallen violently in love at the age of eighteen with the man whom she married would have made her fond of society, of amusement, and perhaps even of dissipation

A12 (17): she would answer with alacrity, "Certainly, Sir Charles" and go off [...].

A13 (17): For the rest it was only so many people more in the servants' hall, at the dinner table and in the drawing room where the evenings were spent. 
A14 (18): Sir Charles was perhaps more acutely aware of this than the Marquis her husband. Sir Charles remembered her as gentle in her changing moods of gaiety and thought, charming, active, fascinating and certainly the most intelligent as she was the most beautiful of the women of the French Court.

A15 (19): distant and dangerous missions to the Courts of North Germany, and northern Italy.

A16 (20) Bernard was acutely aware of her presence and would be certain the Marquise once settled on her sofa to get a flash of a white grin all to himself.

A17 (21): dare to receive an emissary secret or open of the Royal exiles.

A18 (23): he was profoundly moved and without knowing the cause by mere sympathy felt ready to cry himself.

A19 (23): The family had dined with him only the day before as Bernard knew very well because he had to call the hackney coach.

A20 (23): "[...] I fear him wants carry off Mlle. Adèle poor child."

A21 (24): “[...] Why don't you cry with me - you great stupid man."

A22 (24): Bernard fascinated stared upwards at the maid.

A23 (29): dominated by one enormously vital and in its greatness immensely mysterious individuality - the only man of his time.

A24 (33): it was early yet though the last gleams of sunset had gone out completely off the earth and out of the sky.

A25 (33): At a wider spot where several of those lanes met he stopped [...].

A26 (34): In a very few moments he found himself at the door of his inn in a great Square which in comparison with the rest of the town might have been said to blaze with lights.

Sequence B:

B1 (4): Her tall spars overtopped the roofs of the houses, and the English ensign at her flagstaff had just been hauled down and replaced by a lantern [...].

B2 (5): "[...] Why did you do that, in the name of all the saints?"

B3 (7): “[...] Or is it only the darkness that makes her seem so?"

B4 (8): “[...] Different men, different wisdoms."

[...] "Different men, different wisdoms," he repeated, musingly.

B5 (12): For what can you possibly have to do here?

B6 (13): And now, will the signore do what I ask him and return to his inn, which is a much safer place than this platform?

B7 (16): The Englishman beheld with surprise his lately inimical companion squeeze himself between the massive tube of the piece of ordnance and the wall of stone, and wriggle outwards into the depth of the thick embrasure till nothing of him remained visible but his black stockings and the soles of his heavy shoes.

B8 (16): Cosmo, enlisted in these mysterious proceedings, the nature of which was becoming clear enough to him, obeyed at once [...].

B9 (17-18): For wouldn't a ghost be a thing of spirit, a man's soul itself made restless by grief, or love, or remorse, or anger?

B10 (21): his father, Sir Charles, and his sister, Henrietta. 
B11 (24): With habits of meticulous order, and a marvellously commonplace mind, she had a temperament which, if she had not fallen violently in love at the age of eighteen with the man whom she married, would have made her fond of society, of amusement, and perhaps even of dissipation.

B12 (24): She would answer with alacrity, "Certainly, Sir Charles," and go off B13 (25): For the rest it was only so many people more in the servants' hall, at the dinner-table, and in the drawing-room, where the evenings were spent.

B14 (26): Sir Charles was perhaps more acutely aware of this than the marquis, her husband. Sir Charles remembered her as gentle in her changing moods of gaiety and thought, charming, active, fascinating, and certainly the most intelligent, as she was the most beautiful, of the women of the French court.

B15 (27): distant and dangerous missions to the courts of north Germany and northern Italy.

B16 (29): Bernard was acutely aware of her presence and would be certain - the marquise once settled on her sofa - to get a flash of white grin all to himself.

B17 (31): dare to receive an emissary, secret or open, of the royal exiles.

B18 (33): he was profoundly moved and, without knowing the cause, by mere sympathy felt ready to cry himself.

B19 (34): The family had dined with him only the day before, as Bernard knew very well, because he had to call the hackney coach [...].

B20 (34): "[...] fear him wants carry off Mademoiselle Adèle-poor child."

B21 (35): “[...] Why don't you cry with me - you great, stupid man?"

B22 (35): Bernard, fascinated, stared upwards at the maid.

B23 (43): dominated by one enormously vital, and in its greatness, immensely mysterious individuality - the only man of his time.

B24 (49): it was early yet, though the last gleams of sunset had gone completely off the earth and out of the sky.

B25 (49): At a wider spot, where several of those lanes met, he stopped [...].

B26 (51): In a very few moments he found himself at the door of his inn, in a great square which, in comparison with the rest of the town, might have been said to blaze with lights.

Again: it is surely obvious which sequence of passages is the better. It is Sequence B, which uses the text of the first British edition of Suspense (London and Toronto: J. M. Dent \& Sons, 1925). Sequence A was taken from the Cambridge 2011 text of Suspense. The lists are not exhaustive: I could have chosen more examples. An inconsistency in the Cambridge series is that whereas the Rover text italicises foreign words, the Suspense text does not.

Extract A1 illustrates, once more, that widespread failing in the Cambridge edition: too much punctuation has been removed. The reader of A1 initially thinks that "overtopped" governs both "the roofs of houses" and "the English flagstaff", but then, reading on, has to correct that first impression by mentally supplying the absent comma. B1 provides the comma. The comma of B2 again is clarifying. B3, B5, B9 and B21 supply the question-marks incorrectly absent from A3, A5, A9 and A21. 
(This error is sustained to the novel's last page, which offers " Where is his star now,' said Cosmo": p. 192.) In A4, the repetition of the aphorism shows that a comma is missing from the first utterance of it; B4 correctly supplies the comma on both occasions. In B6, the comma after "inn" provides an appropriate pause. The comma in B7 affords a breathing-space in a long otherwise-unpunctuated sentence. A8 has insufficient punctuation, so that the reader at first thinks that "enlisted" is the main verb. On reaching "obeyed", that reader has to re-read the sentence, mentally supplying the commas that B8 provides. In A10, the absence of a comma before "Henrietta" implies that Cosmo has more than one sister. In B10, the presence of the comma shows, correctly, that Cosmo has one sister, Henrietta. A11 is under-punctuated and needs the clarifying pauses given in B11. In A12, the phrase "Certainly, Sir Charles" requires the concluding comma provided by B12. A13 erroneously implies that there are two or more drawing-rooms, in one of which the evenings were spent. B13, with a comma after "the drawing-room" makes clear that there is only one drawing-room. The hyphenated "dinner-table" and "drawing-room" are more precise than the unhyphenated forms. The additional commas of B14 clarify the sense of A14. In A15, the comma after "Germany" prompts the false reading that though the missions to North Germany were to the courts, the mission to northern Italy were not to the courts. B15 corrects the reading. In A15, the capitalisation of "Courts" seems incorrect. The punctuation of B16 is essential to clarify the sense; lacking it, A16 is confusing. Again, the commas of B17 provide necessary clarification. A18, being underpunctuated (in contrast to B18), may initially lead the reader to link "by mere sympathy" to "without knowing the cause" instead of "felt ready". In B19, the commas again provide necessary clarification. A20 needs the punctuation provided by the dash of B20. A21, A22 and A23 are under-punctuated. In A24 the first "out" (absent from B24) is redundant and looks like an erroneous anticipation of the second "out". Compared with A25 and A26, the additional commas of B25 and B26 are clarifying. The capitalisation of "Square" in A26 is erroneous.

To conclude. I submit that what is needed now is an edition of Conrad's literary works which not only includes the new textual matter admirably revealed by the Cambridge editors but also restores to the prose the logical clarity and rhetorical effectiveness which, at times, have unfortunately been removed by those editors. If you agree that my comparative sequences reveal a pattern of flaws, I have made my point. I leave to others the myriad problems of a new edition. 


\section{WORKS CITED}

Conrad, Joseph. Notes on Life and Letters. Ed. J. H. Stape with the assistance of Andrew Busza. Cambridge: Cambridge University Press, 2002.

. The Rover. London: J. M. Dent \& Sons, 1948.

. The Rover. Ed. A. Fachard and J. H. Stape. Cambridge: Cambridge University Press, 2018.

Suspense. London and Toronto: J. M. Dent \& Sons, 1925.

Suspense. Ed. G. M. Moore. Cambridge: Cambridge University Press, 2011. 